\title{
Fludarabine and neurotoxicity in engineered T-cell therapy
}

\author{
Kate L. Lowe ${ }^{1} \cdot$ Crystal L. Mackall ${ }^{2} \cdot$ Elliot Norry $^{3} \cdot$ Rafael Amado $^{3} \cdot$ Bent K. Jakobsen ${ }^{3} \cdot$ Gwendolyn Binder $^{3}$
}

Received: 20 October 2017 / Revised: 25 January 2018 / Accepted: 9 March 2018 / Published online: 7 May 2018

(c) The Author(s) 2018. This article is published with open access

\begin{abstract}
Adoptive T-cell therapy, incorporating engineered T cell receptors (TCRs) or chimeric antigen receptors (CARs), target tumor antigens with high affinity and specificity. To increase the potency of adoptively transferred $\mathrm{T}$ cells, patients are conditioned with lymphodepleting chemotherapy regimens prior to adoptive T-cell transfer (ACT), and data suggest that fludarabine is an important component of an effective regimen. In a recent clinical trial using CAR-T cells engineered to target the CD19 B-cell antigen to treat acute lymphoblastic leukemia, JCAR-015 (NCT02535364), two patient deaths due to cerebral edema led to trial suspension. The lymphodepleting agent fludarabine was suggested as the causative agent, in part due to its known association with neurotoxicity and its ability to induce greater potency. In a similar CAR-T study also incorporating fludarabine in the preconditioning regimen, ZUMA-1 (NCT02348216), one patient died of cerebral edema. However, subsequent deaths in the JCAR-015 study after removal of fludarabine and improved understanding behind the mechanisms of CAR-T-related encephalopathy syndrome (CRES) indicate that fludarabine is not the primary causative agent of cerebral edema and that it can be safely incorporated into the preconditioning regimen for ACT. Since entering clinical use in the late 1980s as a chemotherapy agent, fludarabine and similar analogs have been associated with lethal neurological toxicity, yet the manifestation and timing of symptoms are distinct to those observed recently in ACT. Herein, we review the history of fludarabine development as a chemotherapeutic agent, and discuss the safety of its continued use in preconditioning regimens for ACT.
\end{abstract}

\section{Introduction}

The term "adoptive immunotherapy" was first used to explain the graft-vs.-tumor effect observed following allogeneic stem cell transplants for leukemia [1]. In these early studies, chemotherapy-induced immunosuppression was found to be necessary to enable successful stem cell grafts. Later studies demonstrated the importance of the T-cell component of the stem cell graft in preventing relapse [2]. Allogenic stem cell transplantation (ASCT) signified the first potentially curative approach to improve cancer therapy

Electronic supplementary material The online version of this article (https://doi.org/10.1038/s41434-018-0019-6) contains supplementary material, which is available to authorized users.

$\triangle$ Gwendolyn Binder

Gwen.Binder@adaptimmune.com

1 Immunocore, Oxford, UK

2 Department of Pediatrics, Hematology and Oncology, Stanford Cancer Institute, Stanford, CA, USA

3 Adaptimmune, Oxford, UK, Philadelphia, PA, USA for patients with hematological malignancies, and it was also a first example of cell-based immune oncology.

Lymphodepleting agents were selected based on clinical experience from single agent and combination chemotherapies and include the alkylating agents chlorambucil and cyclophosphamide, which were among the first identified chemotherapeutics. The family of nucleoside analogs shortly followed, encompassing the pyrimidine nucleoside cytarabine and the purine nucleosides cladribine, pentostatin and fludarabine that demonstrate potent cytotoxic activity [3, 4]. Purine nucleosides were developed specifically to improve on the activity of cytarabine, and fludarabine's relative resistance to adenosine deaminase improved its bioavailability. While not used in the original transplant regimens, fludarabine became an important part of pre-transplantation conditioning regimens due to its improved tolerability and outcomes [5-7]. Fludarabine induces cellular cytotoxicity via multiple pathways that ultimately lead to an inhibition of DNA synthesis. A rate-limiting step in this process is the activity of deoxycytidine kinase, which is abundant in lymphocytes, making them susceptible to accumulation of F-ara-ATP, the active metabolite of fludarabine, and hence 


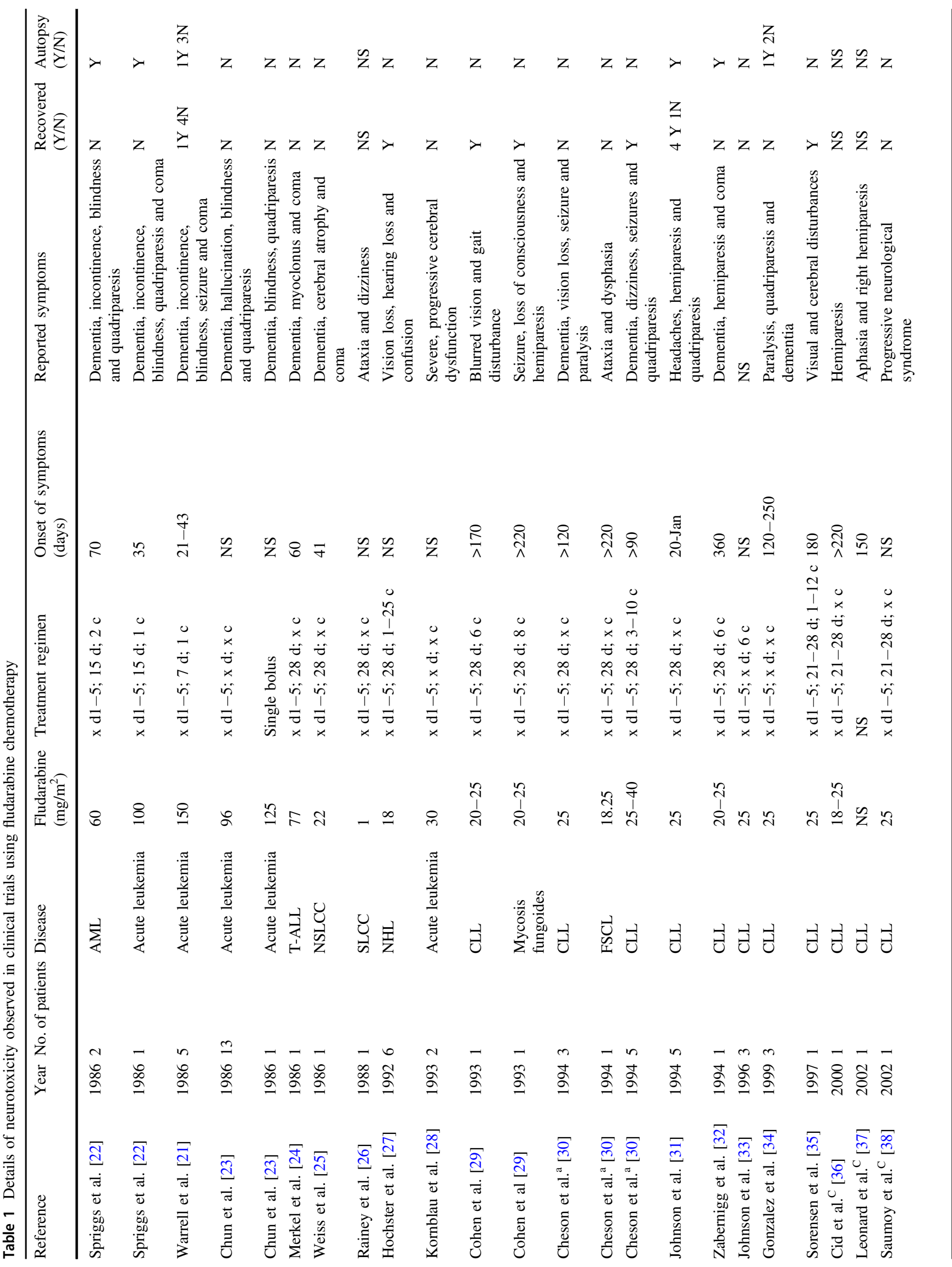


giving fludarabine particularly potent lymphodepleting properties $[8,9]$.

In the setting of adoptive T-cell transfer (ACT)-based immune oncology, use of lymphodepleting chemotherapy enhances potency, in addition to making "room" for the infused cells to engraft [10, 11]. Lymphodepletion was applied to the adoptive transfer of tumor-infiltrating lymphocytes (TILs) for the treatment of metastatic melanoma and led to enhanced TIL homing and anti-tumor efficacy [12]. Use of the non-myeloablative transplant regimen containing fludarabine and cyclophosphamide improved overall response rates compared to patients who did not receive preconditioning, and this regimen therefore was taken forward in a majority of subsequent engineered ACT studies [13]. ACT engineered with chimeric antigen receptors (CARs) and high affinity T-cell receptors (TCRs) targeted against tumor-specific antigens have shown promise in the clinic [14-16].

Recently there have been reports of lethal neurotoxicity due to cerebral edema in six patients treated with CD19 CAR-T cells, across two different CD19 CAR-T studies [17-19]. After the first two patients were reported, links between this neurotoxicity and fludarabine were suggested, as these patients had received fludarabine in addition to cyclophosphamide as part of their preconditioning regimen, and neurotoxicity is known to be associated with this drug. However, the neurological symptoms associated with fludarabine as a chemotherapeutic agent are distinct from CD19 CAR-T neurotoxicity in both symptoms and timing. Specifically, fludarabine-associated neurotoxicity has a later onset, and cerebral edema is not reported. Since initial reports, significant neurotoxicity, including cerebral edema, occurred in the absence of fludarabine-containing preconditioning regimens.

Although it is now broadly accepted that fludarabine is not a primary driver of neurotoxicity at the doses used in ACT studies, it is important to understand its role in the efficacy and toxicity of adoptive T-cell therapy, in order to develop products with the optimal balance of risk and benefit for patients. Here, we summarize the use of fludarabine from a historical perspective to the present day, reporting efficacy and toxicity of fludarabine compared to alternative agents and in different therapeutic regimens, and the rationale for its use in combination with ACT.

\section{History of fludarabine safety and efficacy as a chemotherapeutic agent}

Initial phase I clinical trials testing fludarabine for the treatment of solid tumors started intravenous (i.v.) dosing at $260 \mathrm{mg} / \mathrm{m}^{2}$ for 5 days, which was soon reduced by $60 \%$ due to severe neutropenia [20]. Anti-tumor activity was most 
potent against hematological malignancies resulting in dose escalating Phase II trials for treatment of acute leukemia ( $\geq 100 \mathrm{mg} / \mathrm{m}^{2}$ ) (Supplementary Tables 1 and 2). Although efficacious, high incidence of delayed, progressive central nervous system (CNS) toxicity was reported (described in more detail in the following section). This toxicity was associated with high dose of fludarabine and was addressed by reducing doses to $25-40 \mathrm{mg} / \mathrm{m}^{2}$ for 5 days i.v. in monthly cycles [21-24]. Generally, 25-40 mg/m² dose regimens were well tolerated, although neurotoxic events continued to be reported [25-44] (Table 1, Supplementary Table 2). By the late 1990s, fludarabine-based chemotherapy regimens became the standard first- and second-line therapies for the most common adult leukemia, chronic lymphocytic leukemia (CLL), and a common therapeutic for many other leukemias and lymphomas.

Compared to alternative chemotherapy regimens, fludarabine as a monotherapy produced superior or statistically similar response rates to the chlorambucil, cyclophosphamide-doxorubicin hydrochloride-vincristine (CHOP) regimen, cyclophosphamide-adrianmycin-cisplatin (CAP) regimen and fludarabine-prednisone, with no significant increase in toxic effects. However, no difference in survival was observed (Supplementary Table 3). Combining fludarabine and cyclophosphamide (FC) gave rise to both enhanced response rates and extended survival with no increase in toxicity (Supplementary Table 3). The addition of targeted monoclonal antibodies, such as the anti-CD20 antibody rituximab (FCR) or the anti-CD52 antibody alemutuzumab, further enhanced response and survival in CLL and B-cell non-Hodgkin's lymphoma (B-NHL), although increasing potency also led to increased incidence of toxicity in more vulnerable patients, such as the elderly (Supplementary Table 3). Lowering the dose of FC (FCR-Lite regimens) or replacing $\mathrm{FC}$ with alternate agents such as bendamustine often showed more favorable toxicity profiles, making them more suitable for vulnerable patient populations (Supplementary Table 3).

\section{Fludarabine-induced neurotoxicity}

Fludarabine is rapidly converted in plasma to F-araA, which accumulates in cells where it is phosphorylated to its active metabolite F-araATP by deoxycytidine kinase [9]. This metabolite has a half-life of approximately $20 \mathrm{~h}$ in vivo, and its clearance is dependent upon adequate renal function. The main dose-limiting toxicities associated with fludarabine that are common among chemotherapy agents were myelosuppression and risk of infection, which accounted for the majority of fatalities and failed outcomes. Neurological abnormalities continued to cause concern and were initially confounded by an absence of a mechanism to explain their onset and occurrence. Somnolence and peripheral neuropathy during and immediately following fludarabine infusion were frequently observed but usually reversible, and these symptoms had been described previously with other anti-metabolite drugs [22] (Supplementary Table 2). Of greater concern were the late-onset neurological symptoms (20-250 days) that manifested in a pattern of progressive visual disturbances, peripheral neuropathy, dementia, ataxia, hemiparesis, quadriparesis and blindness, sometimes leading to coma and death (Table 1). Cheson et al. [30] described these late onset symptoms to be associated specifically with purine analogs. While the mechanisms of purine analog-mediated neurotoxicity are still not entirely clear, there is evidence to support the hypothesis that neurotoxicity results from disruption of normal synaptic function. Purine analogs are known to cross the blood brain barrier $(\mathrm{BBB})$, and reduced uptake into the CNS protects against neurotoxicity [45-47]. Adenosine is a major regulator of neuromodulation, and purine analogs have been shown to bind to adenosine receptors [48]. Specifically, fludarabine is an $A_{1}$ receptor agonist [49]. The $A_{1}$ receptor is expressed primarily on neurons, and agonism causes somnolence and may induce coma, while antagonism can induce seizures. The concentration at which fludarabine is predicted to agonize the $\mathrm{A}_{1}$ receptor is pharmacologically relevant for patients receiving higher doses of fludarabine [50].

Where autopsies or MRI could be performed, neurological abnormalities were characterized by demyelination of white matter, variable extents of necrosis, areas of enlarged astrocytes and oligodendrocytes, and multiple lesions in white matter identified by high signal by MRI [21-23, 29, 30, 34, 36, 38, 42, 43] (Table 1). Evidence of JC virus in cerebrospinal fluid or brain biopsies supported the diagnosis of the leukoencephalopathy (LE) or progressive multifocal leukoencephalopathy (PML) [32, 34, 36-39, 44] as a contributing factor to purine analog neurotoxicity. JC virus infects over $70 \%$ of the population and only becomes pathological in immunosuppressive environments, again increasing susceptibility to the elderly and patients with advanced disease. The virus infects oligodendrocytes and astrocytes leading to irreparable degeneration [34]. In the case of CLL, 90\% of PML diagnoses since 1990 occurred in patients treated with purine analogs, such as fludarabine [51].

In summary, fludarabine demonstrated enhanced potency against hematological malignancies compared to alternative agents but was associated with a distinct set of late onset, progressive neurological symptoms in isolated cases. Neurological abnormalities were more prominent at high doses and in more vulnerable patients, such as those with advanced disease or elderly patients that often harbor renal insufficiency, thereby heightening fludarabine exposure. 
Dose reduction of fludarabine is associated with a reduction of these toxicities in patients.

\section{Development of lymphodepleting pre- conditioning regimens for ASCT}

Despite increasing response rates with new combinationbased chemotherapy regimens, patients with advanced hematological malignancies gained little survival advantage until the emergence of ASCT as the first potentially curative treatment strategy $[1,52,53]$. Successful engraftment and durability of cells relied heavily on conditioning the host immune system to "create room" by increasing the levels of homeostatic cytokines including IL-7 and IL-15 and diminishing regulatory mechanisms $[54,55]$.

Myeloablative pre-conditioning regimens were associated with high risk of toxicity and were considered unsuitable in vulnerable patients [56]. While nonmyeloablative regimens reduced toxicity, durability of remission was compromised, leading to the development of reduced intensity conditioning (RIC) regimens that characteristically included a nucleoside analog, such as fludarabine, in combination with an alkylating agent, such as melphalan or busulfan [57-59] (Table 2).

In clinical trials, fludarabine-melphalan (Flu-M) RIC proved superior to FC in increasing engraftment of ASCT and prolonging disease-free survival [53, 59-62] (Table 2). However, non-relapse mortality (NRM) rates that largely resulted from acute graft-vs.-host disease (GVHD) remained high, often correlating with starting disease burden $[58,59,61]$. Efforts to enhance cytotoxic activity of pre-conditioning regimens led to trials replacing fludarabine for a more active nucleoside analog, clofarabine, increasing durability [63-68]. However, RIC regimens consisting of Flu-M, Flu-busulfan, clofarabine-M or clofarabine-busulfan resulted in similar progression-free survival (PFS) and NRM rates across malignancies, making it difficult to dissect optimal treatment strategies [58, 61, 65-77]. Irrespective of individual combinatorial approaches, preconditioning regimens containing nucleoside analogs were associated with increased engraftment and durability of transferred cells.

\section{Fludarabine-associated neurotoxicity in ASCT}

A retrospective analysis of patients receiving fludarabinecontaining pre-conditioning for hematopoietic cell transplantation showed a $2-3 \%$ incidence of grade 3 or higher neurologic events, manifesting in a similar pattern of symptoms to those observed previously from fludarabine alone, from somnolence during infusion, headaches, blurred vision to blindness, seizure, dementia, cognitive decline and paralysis [78]. These chemotherapy-induced LEs can be characterized by MRI as being posterior reversible encephalopathy syndrome (PRES), acute toxic leukoencephalopathy (ATL), or other leukoencephalophathy (OLE), which is similar to ATL but with lesser white matter changes. PRES is associated with better survival outcomes than ATL. The timing of events tended to plateau at onemonth post treatment. A low incidence of neurological events were also recorded in studies reviewed here using either fludarabine or clofarabine preconditioning [43, 58, 63, 64, 71, 74, 78, 79] (Table 2). In a specific case study, neurological symptoms were described to be consistent with LE [43]. Beitinjaneh et al. [78] performed a comprehensive analysis of CNS toxicity associated with fludarabine preconditioning for ASCT. Distinct stages of CNS disease were categorized by MRI and correlated with different forms and severities of LE that influenced survival. Notably, cerebral edema was not described in the imaging findings. The exact occurrence of neurological toxicity following ASCT is likely masked by short follow-up times resulting from disease progression, incidence of GVHD or transition to other treatment regimens.

\section{Lymphodepletion in adoptive T-cell therapy}

\section{TILs}

Following the clinical success of using preconditioning regimens to support engraftment of ASCT for the treatment of both hematological and solid malignancies, the same principle was applied to ACT of TILs for the treatment of metastatic melanoma [80, 81]. Dudley et al. [13, 82] applied FC non-myeloablative conditioning to ACT of TILs cultured from patients with metastatic melanoma and demonstrated enhancement of anti-tumor activity (Table 3). A series of studies expanded on these observations, including combining FC with total body irradiation (supplemented with hematopoietic stem cells) to induce more potent lymphodepletion, resulting in higher objective responses [8387]. The rationale for chemotherapy preconditioning and the mechanisms by which it enhances anti-tumor activity are multi-pronged, including the reduction of immunosuppressive cell populations (e.g. regulatory $\mathrm{T}$ cells and myeloid-derived suppressor cells), an increase in tumor antigen presentation by inducing cell death, a reduction of sinks for the T-cell proliferative cytokines IL-7 and IL-15 and an improvement in the reactivity of the adoptively transferred cells [10, 88, 89].

One major caveat of ACT using TILs is that many cancers are unsuitable for TIL extraction, and the process is 
Table 2 Results from clinical trials using reduced intensity conditioning regimens prior to ASCT

\begin{tabular}{|c|c|c|c|c|c|c|c|}
\hline References & Year & $\begin{array}{l}\text { No. of } \\
\text { patients }\end{array}$ & Disease & $\begin{array}{l}\text { Pre-conditioning } \\
\text { regimen }\end{array}$ & $\begin{array}{l}\text { Engraftment } \\
\text { success }(\%)\end{array}$ & $\begin{array}{l}\text { PFS (\%); } \\
\text { Years (Yr) }\end{array}$ & $\begin{array}{l}\text { NRM (\%); Years } \\
\text { (Yr)/Days (d) }\end{array}$ \\
\hline Giralt et al. [59] & 2001 & 78 & HMs & Flu-M & $80-100$ & $53 ; 1 \mathrm{Yr}$ & $37 ; 100 d$ \\
\hline van Besien et al. [53] & 2003 & 31 & HMs & Flu-M & 100 & $33 ; 1 \mathrm{Yr}$ & 23; NS \\
\hline Schetelig et al. [77] & 2003 & 30 & CLL & Flu-Busulfan & 93 & $67 ; 2 \mathrm{Yr}$ & $15 ; 2 \mathrm{Yr}$ \\
\hline Morris et al. [58] & 2004 & 88 & NHL & Flu-M- Alemtuzumab & 97 & $50 ; 3 \mathrm{Yr}$ & $29 ; 100 d$ \\
\hline \multirow[t]{2}{*}{ Anderlini et al. [60] } & 2005 & 14 & NHL & $\mathrm{FC}$ & 69 & $21 ; 1.5 \mathrm{Yr}$ & $5 ; 1.5 \mathrm{Yr}$ \\
\hline & & 26 & NHL & Flu-M & 100 & $37 ; 1.5 \mathrm{Yr}$ & $22 ; 1.5 \mathrm{Yr}$ \\
\hline Brown et al. [75] & 2006 & 46 & CLL & Flu-Busulfan & $>75$ & $34 ; 2 \mathrm{Yr}$ & $15 ; 2 \mathrm{Yr}$ \\
\hline Delgado et al. [76] & 2006 & 24 & CLL & Flu-M- Alemtuzumab & 85 & $45 ; 2 \mathrm{Yr}$ & $26 ; 2 \mathrm{Yr}$ \\
\hline Oran et al. [61] & 2007 & 112 & AML \& MDS & Flu-M & 82 & $15 ; 2 \mathrm{Yr}$ & $54 ;>2 Y r$ \\
\hline \multirow[t]{2}{*}{ Shimoni et al. [74] } & 2007 & 72 & HMs & Flu-Busulfan & 97 & $72 ; 2 \mathrm{Yr}$ & $16 ; 2 \mathrm{Yr}$ \\
\hline & & 79 & HMs & Flu-M & 99 & $36 ; 2 \mathrm{Yr}$ & $40 ; 2 \mathrm{Yr}$ \\
\hline Anderlini et al. [62] & 2008 & 58 & NHL & Flu-M & NS & $32 ; 2 \mathrm{Yr}$ & $15 ; 2 \mathrm{Yr}$ \\
\hline Valcarcel et al. [69] & 2008 & 93 & AML \& MDS & Flu-Busulfan & NS & $43 ; 4 \mathrm{yr}$ & $16 ; 1 \mathrm{Yr}$ \\
\hline Lee et al. ${ }^{\mathrm{C}}[43]$ & 2010 & 2 & AML & FC & - & - & $2^{\mathrm{a}}$ \\
\hline Beitinjaneh et al. [78] & 2011 & 1596 & $\mathrm{HMs}$ & Flu (+various agents) & NS & NS & NS \\
\hline Santarone et al. [70] & 2011 & 44 & ALL & Flu-Busulfan & 100 & $63 ; 2 \mathrm{Yr}$ & $18 ; 2 \mathrm{Yr}$ \\
\hline Kebriaei et al. [71] & 2012 & 51 & ALL & Clo-Busulfan & 94 & $54 ; 1 \mathrm{Yr}$ & $6 ; 100 \mathrm{~d}$ \\
\hline van Besien et al. [64] & 2012 & 72 & HMs & Clo-M & NS & $45 ; 1 \mathrm{Yr}$ & $26 ; 1 \mathrm{Yr}$ \\
\hline Kirschbaum et al. [63] & 2012 & 14 & HMs & Clo-M & 100 & $61 ;>1 Y r$ & $21 ;<1 \mathrm{Yr}$ \\
\hline \multirow[t]{2}{*}{ Baron et al. [73] } & 2015 & 218 & AML & Flu-Busulfan & 99 & $53 ; 2 \mathrm{Yr}$ & $18 ; 2 \mathrm{Yr}$ \\
\hline & & 176 & & Flu-M & 100 & $60 ; 2 \mathrm{Yr}$ & $20 ; 2 \mathrm{Yr}$ \\
\hline Annalaro et al. ${ }^{\mathrm{C}}$ [79] & 2015 & 1 & Myelofibrosis & Flu & $\mathrm{CR}$ & - & $1^{\mathrm{a}}$ \\
\hline \multirow[t]{2}{*}{ Rambaldi et al. [72] } & 2015 & 125 & AML & Cyc-Busulfan & NS & NS & $17.2 ; 1 \mathrm{Yr}$ \\
\hline & & 127 & AML & Flu-Busulfan & NS & NS & $7.9 ; 1 \mathrm{Yr}$ \\
\hline El-Jawahri et al. [66] & 2016 & 33 & $\begin{array}{l}\text { AML, ALL and } \\
\text { MDS }\end{array}$ & Clo-Busulfan & 100 & $50 ; 2 \mathrm{Yr}$ & $24 ; 1 \mathrm{Yr}$ \\
\hline Alatrash et al. [67] & 2016 & 70 & AML, CML \& MDS & Clo-Flu-Busulfan & 100 & $0.9 \mathrm{Yr}^{\mathrm{b}}$ & $4 ; 100 \mathrm{~d}$ \\
\hline \multirow[t]{2}{*}{ Chevallier et al. [65] } & 2016 & 316 & AML \& MDS & Flu-Busulfan & NS & $51.1 ; 2 \mathrm{Yr}$ & $17.3 ; 2 \mathrm{Yr}$ \\
\hline & & 39 & AML \& MDS & Clo-Busulfan & NS & $61.5 ; 2 \mathrm{Yr}$ & $10.3 ; 2 \mathrm{Yr}$ \\
\hline Kebriaei et al. [68] & 2017 & 107 & ALL & Clo-Busulfan & NS & $44 ; 2 \mathrm{Yr}$ & $34 ; 2 \mathrm{Yr}$ \\
\hline
\end{tabular}

Incidence of NRM were primarily related to opportunistic infections and GVHD-related morbidities, including mucosal, hepatic, pulmonary, renal, cardiac, skin and gastrointestinal

PFS progression-free survival, NRM non-relapse mortality, $N S$ not stated, $C$ case study, $H M s$ hematological malignancies, $C L L$ chronic lymphocytic leukemia, $N H L$ non-Hodgkin's lymphoma, $A M L$ acute myeloid leukemia, $M D S$ myelodysplastic syndromes, $A L L$ acute lymphoblastic leukemia, $C M L$ chronic myeloid leukemia, Flu fludarabine, $M$ melphalan, FC fludarabine-cyclophosphamide, $C l o$ clofarabine

${ }^{a}$ Individual instances of NRM

${ }^{\mathrm{b}}$ Median PFS

both cost and labor intensive [90]. As a result, a search for a more widely applicable ACT methodology has continued, which led to the emergence of genetically modified lymphocytes expressing tumor-targeting receptors in the form of TCRs or CARs.

\section{Engineered TCR-transduced T cells}

TCR engineered T cells are attractive because the TCR recognizes the HLA-peptide complex, and the presented peptides are derived from both membrane and intracellular proteins. This enables TCRs to recognize virtually any protein in the cell, which is useful when engineering specificity for tumor recognition. Affinity optimization of tumor antigen-specific TCR-transduced T cells offers significant advantages over natural affinity TCRs, since the majority of tumor antigens are self-antigens, thus rendering the naturally occurring repertoire of TCRs to be low affinity due to thymic selection mechanisms [91]. Affinity optimization has been shown to improve the potency and 
Table 3 Results from clinical trials using ACT of TILs with or without pre-conditioning regimens

\begin{tabular}{lllllllll}
\hline References & Year & $\begin{array}{l}\text { No. of } \\
\text { patients }\end{array}$ & Disease & $\begin{array}{l}\text { Therapeutic } \\
\text { regimen }\end{array}$ & $\begin{array}{l}\text { CR/ORR } \\
(\%)\end{array}$ & $\begin{array}{l}\text { PFS }>1 \\
\text { year }\end{array}$ & $\begin{array}{l}\text { Neurotoxicity } \\
\leq \text { Grade 3 }\end{array}$ & $\begin{array}{l}\text { Neurotoxicity } \\
\geq \text { Grade } 4\end{array}$ \\
\hline Rosenberg et al. [80] & 1988 & 20 & MM & IL-2 & $-; 55$ & - & - & - \\
Rosenberg et al. [81] & 1994 & 29 & MM & IL-2 & $-; 31$ & - & - & - \\
Rosenberg et al. [81] & 1994 & 57 & MM & FC + IL-2 & $-; 35$ & - & - & - \\
Dudley et al. [13] & 2002 & 13 & MM & FC + IL-2 & $-; 46$ & - & - & - \\
Dudley et al. [82] & 2005 & 35 & MM & FC + IL-2 & $9 ; 51$ & $6 \%$ & - & - \\
Dudley et al. [83] & 2008 & 43 & MM & FC + IL-2 & $9.3 ; 48$ & $9 \%$ & - & - \\
Dudley et al. [83] & 2008 & 25 & MM & FC + TBI + IL-2 & $16 ; 72$ & $12 \%$ & 4 & - \\
Rosenberg et al. [84] & 2011 & 43 & MM & FC + IL-2 & $12 ; 49$ & $12 \%$ & - & - \\
Rosenberg et al. [84] & 2011 & 25 & MM & FC + TBI + IL-2 & $40 ; 72$ & $40 \%$ & - & - \\
Pilon-Thomas et al. [86] & 2012 & 13 & MM & FC + IL-2 & $15 ; 26$ & NS & - & - \\
Besser et al. [87] & 2013 & 54 & MM & FC+ IL-2 & $9 ; 40$ & $9 \%$ & 4 & - \\
Goff et al. [85] & 2016 & 50 & MM & FC + IL-2 & $24 ; 45$ & $24 \%$ & - & - \\
Goff et al. [85] & 2016 & 51 & MM & FC + TBI + IL-2 & $24 ; 54$ & $24 \%$ & -
\end{tabular}

$C R$ complete response, $O R R$ overall response rate, $P F S$ progression-free survival, $M M$ metastatic melanoma, $T I L$ tumor-infiltrating lymphocyte, $I L-2$ interleukin-2, FC fludarabine-cyclophosphamide, TBI today body irradiation

functionality of TCR engineered T cells, which is necessary to recognize immune-selected tumors [92]. TCR-transduced $\mathrm{T}$ cells utilize the natural $\mathrm{T}$-cell signaling infrastructure and therefore maintain the inherent capability to induce physiologically appropriate levels of T-cell activation, costimulation, expansion, memory cell formation and APC interactions [93].

Several TCR engineered T-cell therapy studies have been carried out, including both natural and affinity-optimized TCRs [94]. The antigens MART-1 and gp100 were identified as melanoma-specific antigens during the course of ACT clinical trials with TILs and became the first targets for TCR-transduced T-cell therapy [95-97]. In the majority of these studies, an FC regimen was used for preconditioning. In the first application of ACT using TCR-transduced $\mathrm{T}$ cells for the treatment of metastatic melanoma, response rates were low despite preparative lymphodepletion [95] (Table 4). Efforts to enhance the affinity of TCRs to their target antigen, MART-1, reflected positively in response rates but simultaneously raised issues of enhanced on target, off tumor toxicity, with patients experiencing non-lethal adverse reactions in the skin, eyes and ears due to Mart-1 expression in the cells in those tissues [97]. Subsequent studies expanded into non-melanoma tumors, targeting the NY-ESO-1 cancer testis antigen, with promising results in melanoma and synovial sarcoma $[15,16,98]$. In a TCRtransduced T-cell therapy targeting the cancer testis antigen MAGE-A3, two patients experienced lethal neurological abnormalities said to result from cross-reactivity to other members of the MAGE family that were expressed in brain [99]. A different MAGE-A3 TCR also showed off tumor -off target toxicity in recognition of the cardiomyocyte protein titin, resulting in two patient deaths [100]. In no cases were these adverse events related to use of fludarabine in the preconditioning regimen. Dose reduction of fludarabine is under investigation in a pilot study in synovial sarcoma, as this may reduce other fludarabine-related toxicities such as prolonged neutropenia and bone marrow failure [16]. In this same study, removal of fludarabine appeared to have a negative effect on efficacy.

In summary, the incidence of neurotoxicity appears to be lower with TCR engineered ACT studies, and fludarabine appears to play role in enhancing ACT potency.

\section{CAR-T cells}

CAR-T cells are engineered with synthetic receptors comprised of an antibody single chain variable fragment ( $\mathrm{scFv}$ ) specific for a cell surface protein, a transmembrane domain, and intracellular signaling domains [101]. Secondgeneration CARs incorporate various T-cell costimulatory activation domains such as CD137 (4-1BB) and CD28 to enhance expansion and persistence of the CAR-T cells [102, 103]. Signaling mechanisms are likely to be different with CARs than with TCRs, which harness the natural immunologic synapse, and whether this may lead to differences in the toxicity profiles of the two modalities is an area of active investigation.

As with TIL and TCR-transduced T-cell therapy, preparative lymphodepleting regimens using mainly cyclophosphamide and fludarabine were used to increase efficacy and durability of adoptively transferred CAR-T cells [104-124] (Table 5). In mouse tumor models and human studies, lymphodepletion by cyclophosphamide was 


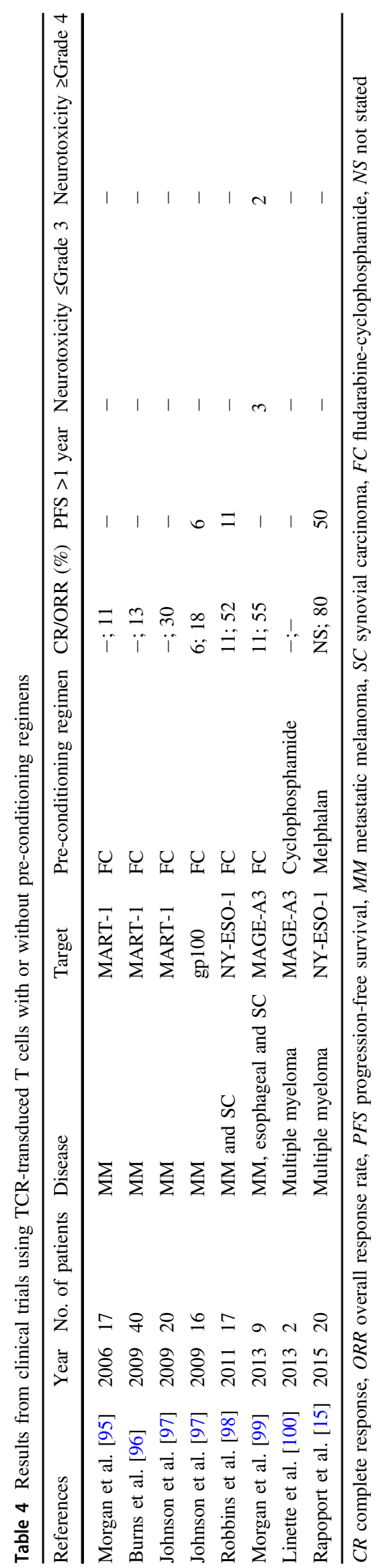

critical for CD19 CAR-T-cell engraftment and persistence $[106,125]$. Fludarabine enhanced in vivo persistence of adoptively transferred $\mathrm{T}$ cells 2.9 fold, in part by reducing starting tumor burden prior to ACT $[106,126]$. Considered here are clinical trials using second-generation CAR-T cells engineered to target B-cell-related hematological malignancies through the CD19 or CD20 surface B-cell antigens. Overall, response rates were much higher than conventional chemotherapy, other ACT methods, and the bispecific antiCD19 BiTE blinatumomab [127] (Table 5).

Few studies have directly compared pre-conditioning regimens; however, trials that did not use pre-conditioning gave rise to substantially lower response rates and PFS [106, 107, 110] (Table 5). Turtle et al. [120] used both cyclophosphamide and FC pre-conditioning regimens and showed that FC improved CAR-T-cell persistence and disease-free survival compared to cyclophosphamide alone. Clear differences in toxicities between lymphodepleting regimens were not described. While enhanced lymphodepletion correlated with increased efficacy and durability of CAR-T cells, deeper conditioning can promote enhanced initial expansion of CAR-T, which along with cell dose and tumor burden, is known to increase the frequency of severe cytokine release syndrome (CRS).

CRS is a systemic inflammatory response caused by high levels of inflammatory cytokines that potentiate T-cell activation and proliferation, and its occurrence in the context of engineered T-cell therapy has a unique algorithm for accurate diagnosis, classification and treatment [128, 129]. CRS can be associated with a broad range of symptoms, often mimicking infection or sepsis. Typical presenting symptoms include fever, anorexia, nausea, fatigue and myalgia/arthralgia, and symptoms can progress to more serious life-threatening complications, including hypotension, capillary leak, and hypoxia. More severe cases can be associated with organ toxicity such as cardiac dysfunction, adult respiratory distress syndrome, and neurologic involvement [118]. In most cases, symptoms of CRS can be effectively managed with supportive care and by blocking the trans IL-6 signaling mechanism through the IL-6 receptor blocking antibody tocilizumab or the IL-6 blocking antibody situximab, and earlier administration provides more effective management of symptoms. Tociluzimab is generally considered not to reduce initial anti-tumor activity, although more research is needed to determine what effect blocking IL-6 activity has on CAR-T cell durability [122]. CRS observed in TCR studies has been less frequent and less severe than in CAR-T studies, which may be due to differences in T-cell signaling, tumor target density, and tumor burden and accessibility [16].

We described earlier a distinct set of late-onset neurological symptoms associated with fludarabine therapy and other purine nucleoside analogs. Neurological events 


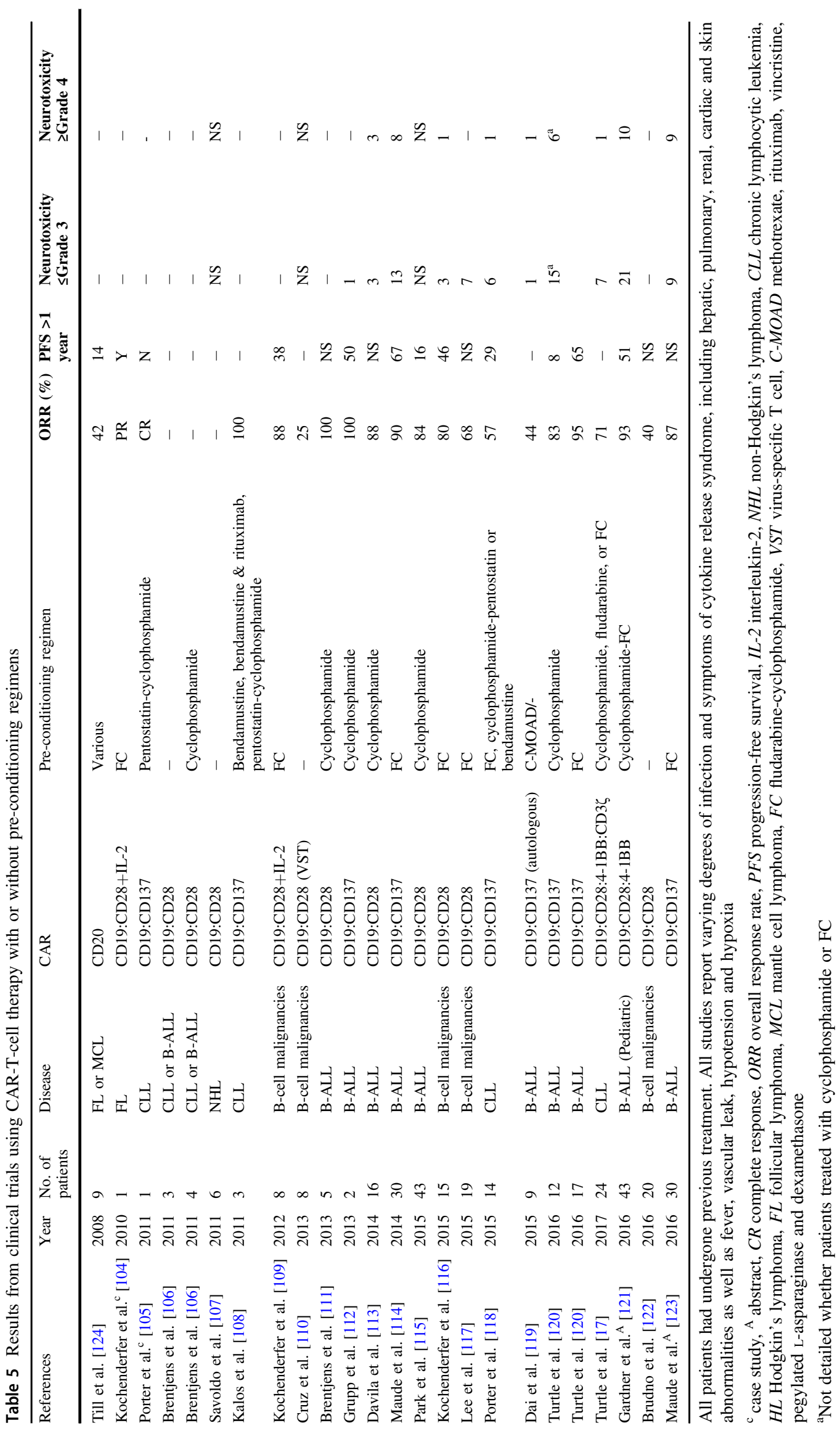


reported following CD19-targeted CAR-T-cell therapy, recently named CAR-T-cell-related encephalopathy syndrome (CRES), manifest in a pattern distinct from that previously described with fludarabine, occurring within the first week of therapy. Several groups reported diagnoses of encephalopathy associated with symptoms of delirium, confusion and hallucinations that occurred soon after CAR$\mathrm{T}$ cell transfer. Symptoms in many cases were severe but reversible [113, 114, 116-118, 120] (Table 5). Factors speculated to contribute to the onset of neurological events include circulating CAR-T-cell concentration and the onset of CRS [117]. Studies identified a correlation between the severity of CRS, the intensity of lymphodepletion and starting tumor burden [111, 113]. In one study, a high incidence of grade 3 or above neurotoxicity $(50 \%)$ was reported using CAR-T cells for treatment of B-ALL. Peak levels of IL-6, IFN- $\gamma$, ferritin, and CRP were significantly higher in patients who developed neurotoxicity. Furthermore, six of six patients with high tumor burden and also treated with higher cell doses developed severe neurotoxicity [120]. In an analysis of the incidence and grade of neurotoxicity, CRS, and correlative biomarkers in blood and CSF in adult patients with relapsed or refractory BALL, severe neurotoxicity correlated with pre-infusion disease burden and peak CAR-T-cell expansion in the blood. Neurotoxicity grade correlated with elevations of CSF protein level as well as elevated cytokines IL6, IL8, IL10, IFN $\gamma$ and G-CSF in CSF over serum at the time of neurotoxicity [130]. These factors suggest a causal role of CRS in the development of neurotoxicity.

CRES is often biphasic, with an initial phase occurring during CRS, and a second phase occurring days later. This second phase may be why some neurological events do not correlate with cytokine levels or CRS. Treatment algorithms for CRES include blockade of IL-6 signaling as well as systemic steroids; however, neurotoxicity has not been consistently responsive to these therapies, making it difficult to elucidate whether early identification and treatment of CRS will be effective in treating neurological symptoms $[116,120,123,129]$. The presentation, time course, proposed monitoring, and treatment algorithm for CRES was recently reported by Neelapu et al. [129].

In a recent clinical trial, JCAR-015 (NCT02535364), investigating the application of CD19 CAR-T cells for the treatment of B-ALL, two patient deaths due to cerebral edema resulted in the trial being suspended, pending investigation. This finding was not previously reported in CAR-T studies. The cerebral edema was initially thought to be associated with the addition of fludarabine to the treatment cohort. Fludarabine was subsequently removed from the preconditioning regimen in the trial; however, two further patient deaths reported shortly after the trial was reinitiated indicated that fludarabine was not the causal agent for the fatal cerebral edema seen in the trial. The trial has since been suspended [131]. Another study, ZUMA-1 (NCT02348216), reported a similar incident, where a patient with advanced refractory NHL experienced cerebral edema following CD19 CAR-T-cell infusion after FC preconditioning, resulting in lethality [132]. This event was an isolated incident, and the trial continued (now complete). However, the CAR constructs engineered for both of these studies share the same CD28 signaling domain, which has been reported to result in greater T-cell expansion [133]. This may contribute to the CRS toxicity and thus neurotoxicity. Investigations into the pathophysiology of these events have recently been reported and include an early endothelial activation event mediated by the CAR-T cells. This initiates a cascade of coagulopathy concomitant with increased BBB permeability. Cytokines produced during CRS, as well as the CAR-T cells, then traffic into the CNS, inducing neurotoxicity [134].

The contribution of the target antigen to neurological abnormalities should be considered. We previously noted the incidence of neurological toxicity within days following adoptive transfer of $\mathrm{T}$ cells transduced with high affinity TCRs against the MAGE-A3 cancer testis antigen, which also cross-reacted with the MAGE-A9 and MAGE-A12 antigens that can be expressed in the CNS. Two patients exhibited lethal global encephalopathy characterized by white matter abnormalities, vacuolation and edema by MRI [99]. Although the cause of toxicity was attributed to crossreactivity with another MAGE family member, the impact of lymphodepletion on the exposure of these potent molecules was not assessed. The contribution of a specific antigen is unique in each case and relates to the level of antigen expression, highlighting the need for thorough research into antigen expression profiles of antigen and related protein sequences.

The spotlight on CD19 CAR-T toxicity is driven by the success and potency of these molecules in the clinic. Interestingly, early results in a primate model suggest that similar neurotoxicity occurs following treatment with CD20 CAR-T cells [135]. In a small number of non-human primates, CRS and neurotoxicity were recapitulated following infusion of CD20 CAR-T cells in healthy animals following preconditioning with cyclophosphamide alone. The autopsy of the animals showed extensive infiltration into the brain of CD20 ${ }^{+}$CAR-T cells [135]. This increased CNS infiltration may be due to the CAR-T cells reacting to naturally trafficking B cells in the brain parenchyma [136]. Furthermore, CD19 CAR-T cells have been identified in the CSF of some subjects with neurotoxicity and the extent of infiltration correlates with severity in some but not all studies [117, 119, 130]. Neurotoxicity with encephalopathic symptoms has also been described with the bispecific anti-CD19 BiTE blinatumomab. Despite the recently described 
pathophysiology of CD19 CAR-T-mediated neurotoxicity described earlier, the significance of CD19 or other antigens on the mechanism of neurological toxicity cannot be excluded and will only be further understood with continuing evaluation of affected subjects and as increasing numbers of CAR-T cells targeting different antigens are tested for a range of malignancies.

\section{Conclusions}

The early onset neurological symptoms observed following CD19 CAR-T-cell therapy that include encephalopathy and more rarely cerebral edema appear to be driven by a distinct set of mechanisms from those that drive late-onset neurological toxicity associated directly with fludarabine. To our knowledge, late-onset neurotoxicity associated with fludarabine has not been reported in ACT studies. There should be careful monitoring for this potential toxicity, particularly in patients with increased sensitivity to fludarabine, such as heavily pre-treated patients or patients with renal insufficiency.

The mechanisms that induce early onset cerebral edema are just beginning to be elucidated. CRES severity is highly correlated with CRS severity, which is known to be related to expansion of CAR-T cells in vivo. As suspected then, risk factors for CRES include tumor burden and the depth of preconditioning, as both of these factors affect the expansion of infused $\mathrm{T}$ cells. This may explain why the first cerebral edema events on the JCAR015 study were seen once fludarabine was added to the preconditioning regimen, as it leads to a more profound lymphopenia. Presence of the target in the CNS (e.g. on B cells circulating through the CNS) may also contribute to CRES. CRES is a common neurotoxic side effect in CAR-T-cell studies, and similar side effects appear to be less frequent and less severe in TCR and TIL studies. Although encephalopathy can be severe, complete recovery is typical. A second neurological toxicity, cerebral edema, has only rarely been observed in CAR-Tcell studies, has not been observed to date in TCR T cell studies, and is acutely life threatening. It now appears that cerebral edema is an extreme manifestation of CRES. The recent elucidation of the mechanism behind this toxicity and components of the etiology with other described medical events, such as thrombotic thrombocytopenic purpura and malaria-associated neurologic dysfunction, suggest approaches for therapeutic intervention [137]. Early identification of certain biomarkers and careful management of CRS may help reduce side effects of neurotoxicity [129]

Fludarabine is an important component of the preconditioning regimen for effective ACT. Consideration of the intensity of fludarabine preconditioning should include reduction of dose for patients with known risk factors for fludarabine toxicity, as described in the product label. Next generation engineered T-cell therapies that include approaches to circumvent the requirement for preconditioning may lead to ACT regimens with improved tolerability. Until then, fludarabine continues to be an important component of the preconditioning regimen for supporting the potency of ACT. At doses used in this context, the evidence to date does not support a direct role for fludarabine in initiation or exacerbation of CRES.

\section{Compliance with ethical standards}

Conflict of interest KLL is an employee of Immunocore; EN, RA, $\mathrm{BKJ}$ and GB are employees of Adaptimmune. CLM is a member of the Parker Institute for Cancer Immunotherapy, which supports the Stanford University Cancer Immunotherapy Program.

Open Access This article is licensed under a Creative Commons Attribution 4.0 International License, which permits use, sharing, adaptation, distribution and reproduction in any medium or format, as long as you give appropriate credit to the original author(s) and the source, provide a link to the Creative Commons license, and indicate if changes were made. The images or other third party material in this article are included in the article's Creative Commons license, unless indicated otherwise in a credit line to the material. If material is not included in the article's Creative Commons license and your intended use is not permitted by statutory regulation or exceeds the permitted use, you will need to obtain permission directly from the copyright holder. To view a copy of this license, visit http://creativecommons. org/licenses/by/4.0/.

\section{References}

1. Mathe G, Amiel JL, Schwarzenberg L, Cattan A, Schneider M, Devries MJ, et al. Successful Allogenic Bone Marrow Transplantation in Man: Chimerism, Induced Specific Tolerance and Possible Anti-Leukemic Effects. Blood. 1965;25:179-96.

2. Horowitz MM, Gale RP, Sondel PM, Goldman JM, Kersey J, Kolb HJ, et al. Graft-versus-leukemia reactions after bone marrow transplantation. Blood. 1990;75:555-62.

3. DeVita VT Jr., Chu E. A history of cancer chemotherapy. Cancer Res. 2008;68:8643-53.

4. Chun HG, Leyland-Jones B, Cheson BD. Fludarabine phosph/ ate: a synthetic purine antimetabolite with significant activity against lymphoid malignancies. J Clin Oncol. 1991;9:175-88.

5. Srinivasan R, Takahashi Y, McCoy JP, Espinoza-Delgado I, Dorrance $\mathrm{C}$, Igarashi $\mathrm{T}$, et al. Overcoming graft rejection in heavily transfused and allo-immunised patients with bone marrow failure syndromes using fludarabine-based haematopoietic cell transplantation. Br J Haematol. 2006;133:305-14.

6. George B, Mathews V, Shaji RV, Srivastava V, Srivastava A, Chandy M. Fludarabine-based conditioning for allogeneic stem cell transplantation for multiply transfused patients with Fanconi's anemia. Bone Marrow Transplant. 2005;35:341-3.

7. Dhere V, Edelman S, Waller EK, Langston A, Graiser M, Connolly EC, et al. Myeloablative busulfan/cytoxan conditioning versus reduced-intensity fludarabine/melphalan conditioning for allogeneic hematopoietic stem cell transplant in patients with acute myelogenous leukemia. Leuk Lymphoma 2017;59:1-7.

8. Fidias P, Chabner BA, Grossbard ML. Purine Analogs for the Treatment of Low-Grade Lymphoproliferative Disorders. Oncologist. 1996;1:125-39. 
9. Gandhi V, Plunkett W. Cellular and clinical pharmacology of fludarabine. Clin Pharmacokinet. 2002;41:93-103.

10. Gattinoni L, Finkelstein SE, Klebanoff CA, Antony PA, Palmer DC, Spiess PJ, et al. Removal of homeostatic cytokine sinks by lymphodepletion enhances the efficacy of adoptively transferred tumor-specific CD8 + T cells. J Exp Med. 2005;202:907-12.

11. Klebanoff CA, Khong HT, Antony PA, Palmer DC, Restifo NP. Sinks, suppressors and antigen presenters: how lymphodepletion enhances $\mathrm{T}$ cell-mediated tumor immunotherapy. Trends Immunol. 2005;26:111-7.

12. Griffith KD, Read EJ, Carrasquillo JA, Carter CS, Yang JC, Fisher B, et al. In vivo distribution of adoptively transferred indium-111-labeled tumor infiltrating lymphocytes and peripheral blood lymphocytes in patients with metastatic melanoma. J Natl Cancer Inst. 1989;81:1709-17.

13. Dudley ME, Wunderlich JR, Yang JC, Hwu P, Schwartzentruber DJ, Topalian SL, et al. A phase I study of nonmyeloablative chemotherapy and adoptive transfer of autologous tumor antigen-specific $\mathrm{T}$ lymphocytes in patients with metastatic melanoma. J Immunother. 2002;25:243-51.

14. Riaz IB, Zahid U, Kamal MU, Husnain M, McBride A, Hua A, et al. Anti-CD 19 and anti-CD 20 CAR-modified T cells for Bcell malignancies: a systematic review and meta-analysis. Immunotherapy. 2017;9:979-93.

15. Rapoport AP, Stadtmauer EA, Binder-Scholl GK, Goloubeva O, Vogl DT, Lacey SF, et al. NY-ESO-1-specific TCR-engineered $\mathrm{T}$ cells mediate sustained antigen-specific antitumor effects in myeloma. Nat Med. 2015;21:914-21.

16. Mackall C, Tap WD, Glod J, Druta M, Chow WA, Araujo DM, Grupp SA, Van Tine BA, Chagin K, Van Winkle E, Kari G, Trivedi T, Norry E, Holdich T, Bartlett-Pandite AN, Amado RG, D'Angelo SP. Open label, non-randomized, multi-cohort pilot study of genetically engineered NY-ESO-1c259T in HLA-A2+ patients with synovial sarcoma (NCT01343043). J Clin Oncol. 2017;35(15 suppl):p3000.

17. Turtle CJ, Hay KA, Hanafi LA, Li D, Cherian S, Chen X, et al. Durable molecular remissions in chronic lymphocytic leukemia treated with CD19-specific chimeric antigen receptor-modified $\mathrm{T}$ cells after failure of ibrutinib. J Clin Oncol: Off J Am Soc Clin Oncol. 2017;35:3010-20.

18. Juno Therapeutics places JCAR015 phase II ROCKET trial on clinical hold [press release]. 11/23/16. 2016.

19. Locke FL, Neelapu SS, Bartlett NL,Siddiqi T, Chavez JC,Hosing $\mathrm{CM}$, et al. Phase 1 clinical results of the ZUMA-1 (KTE-C19101) study: a phase 1-2 multi-center study evaluating the safety and efficacy of anti-CD19 CAR T cells (KTE-C19) in subjects with refractory aggressive non-Hodgkin lymphoma (NHL). Blood. 2015;126:3991.

20. Malspeis L, Grever MR, Staubus AE, Young D. Pharmacokinetics of 2-F-ara-A (9-beta-D-arabinofuranosyl-2-fluoroadenine) in cancer patients during the phase I clinical investigation of fludarabine phosphate. Semin Oncol. 1990;17(5Suppl 8): $18-32$.

21. Warrell RP Jr., Berman E. Phase I and II study of fludarabine phosphate in leukemia: therapeutic efficacy with delayed central nervous system toxicity. J Clin Oncol. 1986;4:74-9.

22. Spriggs DR, Stopa E, Mayer RJ, Schoene W, Kufe DW. Fludarabine phosphate (NSC 312878) infusions for the treatment of acute leukemia: phase I and neuropathological study. Cancer Res. 1986;46:5953-8.

23. Chun HG, Leyland-Jones BR, Caryk SM, Hoth DF. Central nervous system toxicity of fludarabine phosphate. Cancer Treat Rep. 1986;70:1225-8.

24. Merkel DE, Griffin NL, Kagan-Hallet K, Von Hoff DD. Central nervous system toxicity with fludarabine. Cancer Treat Rep. 1986;70:1449-50.
25. Weiss GR, Crowley J, Von Hoff DD, Taylor SA, Belt RJ, Coltman CA Jr., et al. Phase II study of fludarabine phosphate for the treatment of advanced non-small cell carcinoma of the lung: a Southwest Oncology Group Study. Cancer Treat Rep. 1986;70:1123-4.

26. Rainey JM, Hill JB, Crowley J. Evaluation of fludarabine phosphate in small cell carcinoma. A Southwest Oncology Group Study. Invest New Drugs. 1988;6:45-6.

27. Hochster HS, Kim KM, Green MD, Mann RB, Neiman RS, Oken MM, et al. Activity of fludarabine in previously treated non-Hodgkin's low-grade lymphoma: results of an Eastern Cooperative Oncology Group study. J Clin Oncol. 1992;10:28-32.

28. Kornblau SM, Cortes-Franco J, Estey E. Neurotoxicity associated with fludarabine and cytosine arabinoside chemotherapy for acute leukemia and myelodysplasia. Leukemia. 1993;7:378-83.

29. Cohen RB, Abdallah JM, Gray JR, Foss F. Reversible neurologic toxicity in patients treated with standard-dose fludarabine phosphate for mycosis fungoides and chronic lymphocytic leukemia. Ann Intern Med. 1993;118:114-6.

30. Cheson BD, Vena DA, Foss FM, Sorensen JM. Neurotoxicity of purine analogs: a review. J Clin Oncol. 1994;12:2216-28.

31. Johnson PW, Fearnley J, Domizio P, Goldin J, Nagendran K, Gawler J, et al. Neurological illness following treatment with fludarabine. Br J Cancer. 1994;70:966-8.

32. Zabernigg A, Maier H, Thaler J, Gattringer C. Late-onset fatal neurological toxicity of fludarabine. Lancet. 1994;344:1780.

33. Johnson S, Smith AG, Loffler H, Osby E, Juliusson G, Emmerich B, et al. Multicentre prospective randomised trial of fludarabine versus cyclophosphamide, doxorubicin, and prednisone (CAP) for treatment of advanced-stage chronic lymphocytic leukaemia. The French Cooperative Group on CLL. Lancet. 1996;347:1432-8.

34. Gonzalez H, Bolgert F, Camporo P, Leblond V. Progressive multifocal leukoencephalitis (PML) in three patients treated with standard-dose fludarabine (FAMP). Hematol Cell Ther. 1999;41:183-6.

35. Sorensen JM, Vena DA, Fallavollita A, Chun HG, Cheson BD. Treatment of refractory chronic lymphocytic leukemia with fludarabine phosphate via the group $\mathrm{C}$ protocol mechanism of the National Cancer Institute: five-year follow-up report. J Clin Oncol. 1997;15:458-65.

36. Cid J, Revilla M, Cervera A, Cervantes F, Munoz E, Ferrer I, et al. Progressive multifocal leukoencephalopathy following oral fludarabine treatment of chronic lymphocytic leukemia. Ann Hematol. 2000;79:392-5.

37. Leonard S, Hulin C, Anxionnat R, Grignon Y, Taillandier L, Vespignani H. [Multifocal progressive leukoencephalitis in a patient given fludarabine for chronic lymphoid leukemia]. Rev Neurol (Paris). 2002;158:1121-3.

38. Saumoy M, Castells G, Escoda L, Mares R, Richart C, Ugarriza A. Progressive multifocal leukoencephalopathy in chronic lymphocytic leukemia after treatment with fludarabine. Leuk Lymphoma. 2002;43:433-6.

39. Kiewe P, Seyfert S, Korper S, Rieger K, Thiel E, Knauf W. Progressive multifocal leukoencephalopathy with detection of JC virus in a patient with chronic lymphocytic leukemia parallel to onset of fludarabine therapy. Leuk Lymphoma. 2003;44:1815-8.

40. Rossi JF, van Hoof A, de Boeck K, Johnson SA, Bron D, Foussard C, et al. Efficacy and safety of oral fludarabine phosphate in previously untreated patients with chronic lymphocytic leukemia. J Clin Oncol. 2004;22:1260-7.

41. Hagenbeek A, Eghbali H, Monfardini S, Vitolo U, Hoskin PJ, de Wolf-Peeters C, et al. Phase III intergroup study of fludarabine phosphate compared with cyclophosphamide, vincristine, and 
prednisone chemotherapy in newly diagnosed patients with stage III and IV low-grade malignant Non-Hodgkin's lymphoma. J Clin Oncol. 2006;24:1590-6.

42. Kalita J, Patel NS, Misra UK. Magnetic resonance imaging may simulate progressive multifocal leucoencephalopathy in a patient with chronic lymphocytic leukemia after fludarabine therapy. Ann Indian Acad Neurol. 2008;11:114-5.

43. Lee MS, McKinney AM, Brace JR, Santacruz K. Clinical and imaging features of fludarabine neurotoxicity. $\mathrm{J}$ neuroOphthalmol. 2010;30:37-41.

44. Lejniece S, Murovska M, Chapenko S, Breiksa B, Jaunmuktane $\mathrm{Z}$, Feldmane L, et al. Progressive multifocal leukoencephalopathy following fludarabine treatment in a chronic lymphocytic leukemia patient. Exp Oncol. 2011;33:239-41.

45. Adjei AA, Dagnino L, Wong MM, Paterson AR. Protection against fludarabine neurotoxicity in leukemic mice by the nucleoside transport inhibitor nitrobenzylthioinosine. Cancer Chemother Pharmacol. 1992;31:71-5.

46. Major PP, Agarwal RP, Kufe DW. Deoxycoformycin: neurological toxicity. Cancer Chemother Pharmacol. 1981;5:193-6.

47. Grever MR, Siaw MF, Jacob WF, Neidhart JA, Miser JS, Coleman MS, et al. The biochemical and clinical consequences of 2'-deoxycoformycin in refractory lymphoproliferative malignancy. Blood. 1981;57:406-17.

48. Ribeiro JA, Sebastiao AM, de Mendonca A. Adenosine receptors in the nervous system: pathophysiological implications. Prog Neurobiol. 2002;68:377-92.

49. Jensen K, Johnson LA, Jacobson PA, Kachler S, Kirstein MN, Lamba J, et al. Cytotoxic purine nucleoside analogues bind to A1, A2A, and A3 adenosine receptors. Naunyn-Schmiedeberg's Arch Pharmacol. 2012;385:519-25.

50. Long-Boyle JR, Green KG, Brunstein CG, Cao Q, Rogosheske J, Weisdorf DJ, et al. High fludarabine exposure and relationship with treatment-related mortality after nonmyeloablative hematopoietic cell transplantation. Bone Marrow Transplant. 2011;46:20-6.

51. Isidoro L, Pires P, Rito L, Cordeiro G. Progressive multifocal leukoencephalopathy in a patient with chronic lymphocytic leukaemia treated with alemtuzumab. BMJ Case Reports. 2014;2014. pii: bcr2013201781.

52. Dickinson AM, Norden J, Li S, Hromadnikova I, Schmid C, Schmetzer $\mathrm{H}$, et al. Graft-versus-leukemia effect following hematopoietic stem cell transplantation for leukemia. Front Immunol. 2017;8:496.

53. Van Besien K, Devine S, Wickrema A, Jessop E, Amin K, Yassine $\mathrm{M}$, et al. Regimen-related toxicity after fludarabinemelphalan conditioning: a prospective study of 31 patients with hematologic malignancies. Bone Marrow Transplant. 2003;32:471-6.

54. Sandau MM, Winstead CJ, Jameson SC. IL-15 is required for sustained lymphopenia-driven proliferation and accumulation of CD8 T cells. J Immunol. 2007;179:120-5.

55. Fry TJ, Connick E, Falloon J, Lederman MM, Liewehr DJ, Spritzler J, et al. A potential role for interleukin-7 in T-cell homeostasis. Blood. 2001;97:2983-90.

56. Ricci F, Tedeschi A, Morra E, Montillo M. Fludarabine in the treatment of chronic lymphocytic leukemia: a review. Ther Clin Risk Manag. 2009;5:187-207.

57. Bethge WA, Hegenbart U, Stuart MJ, Storer BE, Maris MB, Flowers ME, et al. Adoptive immunotherapy with donor lymphocyte infusions after allogeneic hematopoietic cell transplantation following nonmyeloablative conditioning. Blood. 2004;103:790-5.

58. Morris E, Thomson K, Craddock C, Mahendra P, Milligan D, Cook $\mathrm{G}$, et al. Outcomes after alemtuzumab-containing reducedintensity allogeneic transplantation regimen for relapsed and refractory non-Hodgkin lymphoma. Blood. 2004;104: 3865-71.

59. Giralt S, Thall PF, Khouri I, Wang X, Braunschweig I, Ippolitti $\mathrm{C}$, et al. Melphalan and purine analog-containing preparative regimens: reduced-intensity conditioning for patients with hematologic malignancies undergoing allogeneic progenitor cell transplantation. Blood. 2001;97:631-7.

60. Anderlini P, Saliba R, Acholonu S, Okoroji GJ, Donato M, Giralt $\mathrm{S}$, et al. Reduced-intensity allogeneic stem cell transplantation in relapsed and refractory Hodgkin's disease: low transplant-related mortality and impact of intensity of conditioning regimen. Bone Marrow Transplant. 2005;35:943-51.

61. Oran B, Giralt S, Saliba R, Hosing C, Popat U, Khouri I, et al. Allogeneic hematopoietic stem cell transplantation for the treatment of high-risk acute myelogenous leukemia and myelodysplastic syndrome using reduced-intensity conditioning with fludarabine and melphalan. Biol Blood Marrow Transplant. 2007;13:454-62.

62. Anderlini P, Saliba R, Acholonu S, Giralt SA, Andersson B, Ueno NT, et al. Fludarabine-melphalan as a preparative regimen for reduced-intensity conditioning allogeneic stem cell transplantation in relapsed and refractory Hodgkin's lymphoma: the updated M.D. Anderson Cancer Center experience. Haematologica. 2008;93:257-64.

63. Kirschbaum MH, Stein AS, Popplewell L, Delioukina M, Chen R, Nakamura R, et al. A phase I study in adults of clofarabine combined with high-dose melphalan as reduced-intensity conditioning for allogeneic transplantation. Biol Blood Marrow Transplant. 2012;18:432-40.

64. van Besien K, Stock W, Rich E, Odenike O, Godley LA, O'Donnell PH, et al. Phase I-II study of clofarabine-melphalanalemtuzumab conditioning for allogeneic hematopoietic cell transplantation. Biol Blood Marrow Transplant. 2012; 18:913-21.

65. Chevallier P, Labopin M, de La Tour RP, Lioure B, Bulabois $\mathrm{CE}$, Huynh A, et al. Clofarabine versus fludarabine-based reduced-intensity conditioning regimen prior to allogeneic transplantation in adults with AML/MDS. Cancer Med. 2016;5:3068-76.

66. El-Jawahri A, Li S, Ballen KK, Cutler C, Dey BR, Driscoll J, et al. Phase II trial of reduced-intensity busulfan/clofarabine conditioning with allogeneic hematopoietic stem cell transplantation for patients with acute meloid leukemia, myelodysplastic syndromes, and acute lymphoid leukemia. Biol Blood Marrow Transplant. 2016;22:80-5.

67. Alatrash G, Thall PF, Valdez BC, Fox PS, Ning J, Garber HR, et al. Long-term outcomes after treatment with clofarabine $+/-$ fludarabine with once-daily intravenous busulfan as pretransplant conditioning therapy for advanced myeloid leukemia and myelodysplastic syndrome. Biol Blood Marrow Transplant. 2016;22:1792-800.

68. Kebriaei P, Bassett R, Lyons G, Valdez B, Ledesma C, Rondon $\mathrm{G}$, et al. Clofarabine plus busulfan is an effective conditioning regimen for allogeneic hematopoietic stem cell transplantation in patients with acute lymphoblastic leukemia: long-term study results. Biol Blood Marrow Transplant. 2017;23:285-92.

69. Valcarcel D, Martino R, Caballero D, Martin J, Ferra C, Nieto $\mathrm{JB}$, et al. Sustained remissions of high-risk acute myeloid leukemia and myelodysplastic syndrome after reduced-intensity conditioning allogeneic hematopoietic transplantation: chronic graft-versus-host disease is the strongest factor improving survival. J Clin Oncol. 2008;26:577-84.

70. Santarone S, Pidala J, Di Nicola M, Field T, Alsina M, Ayala E, et al. Fludarabine and pharmacokinetic-targeted busulfan before allografting for adults with acute lymphoid leukemia. Biol Blood Marrow Transplant. 2011;17:1505-11. 
71. Kebriaei P, Basset R, Ledesma C, Ciurea S, Parmar S, Shpall EJ, et al. Clofarabine combined with busulfan provides excellent disease control in adult patients with acute lymphoblastic leukemia undergoing allogeneic hematopoietic stem cell transplantation. Biol Blood Marrow Transplant. 2012;18:1819-26.

72. Rambaldi A, Grassi A, Masciulli A, Boschini C, Mico MC, Busca A, et al. Busulfan plus cyclophosphamide versus busulfan plus fludarabine as a preparative regimen for allogeneic haemopoietic stem-cell transplantation in patients with acute myeloid leukaemia: an open-label, multicentre, randomised, phase 3 trial. Lancet Oncol. 2015;16:1525-36.

73. Baron F, Labopin M, Peniket A, Jindra P, Afanasyev B, Sanz $\mathrm{MA}$, et al. Reduced-intensity conditioning with fludarabine and busulfan versus fludarabine and melphalan for patients with acute myeloid leukemia: a report from the Acute Leukemia Working Party of the European Group for Blood and Marrow Transplantation. Cancer . 2015;121:1048-55.

74. Shimoni A, Hardan I, Shem-Tov N, Rand A, Herscovici C, Yerushalmi R, et al. Comparison between two fludarabine-based reduced-intensity conditioning regimens before allogeneic hematopoietic stem-cell transplantation: fludarabine/melphalan is associated with higher incidence of acute graft-versus-host disease and non-relapse mortality and lower incidence of relapse than fludarabine/busulfan. Leukemia. 2007;21:2109-16.

75. Brown JR, Kim HT, Li S, Stephans K, Fisher DC, Cutler C, et al. Predictors of improved progression-free survival after nonmyeloablative allogeneic stem cell transplantation for advanced chronic lymphocytic leukemia. Biol Blood Marrow Transplant: J Am Soc Blood Marrow Transplant. 2006;12:1056-64.

76. Delgado J, Thomson K, Russell N, Ewing J, Stewart W, Cook G, et al. Results of alemtuzumab-based reduced-intensity allogeneic transplantation for chronic lymphocytic leukemia: a British Society of Blood and Marrow Transplantation Study. Blood. 2006;107:1724-30.

77. Schetelig J, Thiede C, Bornhauser M, Schwerdtfeger R, Kiehl M, Beyer J, et al. Evidence of a graft-versus-leukemia effect in chronic lymphocytic leukemia after reduced-intensity conditioning and allogeneic stem-cell transplantation: the Cooperative German Transplant Study Group. J Clin Oncol. 2003;21:2747-53.

78. Beitinjaneh A, McKinney AM, Cao Q, Weisdorf DJ. Toxic leukoencephalopathy following fludarabine-associated hematopoietic cell transplantation. Biol Blood Marrow Transplant. 2011;17:300-8.

79. Annaloro C, Costa A, Fracchiolla NS, Mometto G, Artuso S, Saporiti G, et al. Severe fludarabine neurotoxicity after reduced intensity conditioning regimen to allogeneic hematopoietic stem cell transplantation: a case report. Clin Case Rep. 2015;3:650-5.

80. Rosenberg SA, Packard BS, Aebersold PM, Solomon D, Topalian SL, Toy ST, et al. Use of tumor-infiltrating lymphocytes and interleukin-2 in the immunotherapy of patients with metastatic melanoma. A preliminary report. $\mathrm{N}$ Eng J Med. 1988;319:1676-80.

81. Rosenberg SA, Yannelli JR, Yang JC, Topalian SL, Schwartzentruber DJ, Weber JS, et al. Treatment of patients with metastatic melanoma with autologous tumor-infiltrating lymphocytes and interleukin 2. J Natl Cancer Inst. 1994;86:1159-66.

82. Dudley ME, Wunderlich JR, Yang JC, Sherry RM, Topalian SL, Restifo NP, et al. Adoptive cell transfer therapy following nonmyeloablative but lymphodepleting chemotherapy for the treatment of patients with refractory metastatic melanoma. J Clin Oncol. 2005;23:2346-57.

83. Dudley ME, Yang JC, Sherry R, Hughes MS, Royal R, Kammula $U$, et al. Adoptive cell therapy for patients with metastatic melanoma: evaluation of intensive myeloablative chemoradiation preparative regimens. J Clin Oncol. 2008;26:5233-9.
84. Rosenberg SA, Yang JC, Sherry RM, Kammula US, Hughes MS, Phan GQ, et al. Durable complete responses in heavily pretreated patients with metastatic melanoma using T-cell transfer immunotherapy. Clin Cancer Res. 2011;17:4550-7.

85. Goff SL, Dudley ME, Citrin DE, Somerville RP, Wunderlich JR, Danforth DN, et al. Randomized, prospective evaluation comparing intensity of lymphodepletion before adoptive transfer of tumor-infiltrating lymphocytes for patients with metastatic melanoma. J Clin Oncol. 2016;34:2389-97.

86. Pilon-Thomas S, Kuhn L, Ellwanger S, Janssen W, Royster E, Marzban S, et al. Efficacy of adoptive cell transfer of tumorinfiltrating lymphocytes after lymphopenia induction for metastatic melanoma. J Immunother. 2012;35:615-20.

87. Besser MJ, Shapira-Frommer R, Itzhaki O, Treves AJ, Zippel DB, Levy D, et al. Adoptive transfer of tumor-infiltrating lymphocytes in patients with metastatic melanoma: intent-to-treat analysis and efficacy after failure to prior immunotherapies. Clin Cancer Res. 2013;19:4792-800.

88. Wrzesinski C, Restifo NP. Less is more: lymphodepletion followed by hematopoietic stem cell transplant augments adoptive T-cell-based anti-tumor immunotherapy. Curr Opin Immunol. 2005;17:195-201.

89. Muranski P, Boni A, Wrzesinski C, Citrin DE, Rosenberg SA, Childs R, et al. Increased intensity lymphodepletion and adoptive immunotherapy-how far can we go? Nat Clin Pract Oncol. 2006;3:668-81.

90. Rosenberg SA, Restifo NP. Adoptive cell transfer as personalized immunotherapy for human cancer. Science. 2015; 348:62-8.

91. Aleksic M, Liddy N, Molloy PE, Pumphrey N, Vuidepot A, Chang KM, et al. Different affinity windows for virus and cancer-specific T-cell receptors: implications for therapeutic strategies. Eur J Immunol. 2012;42:3174-9.

92. Tan MP, Gerry AB, Brewer JE, Melchiori L, Bridgeman JS, Bennett $\mathrm{AD}$, et al. $\mathrm{T}$ cell receptor binding affinity governs the functional profile of cancer-specific CD8 $+\mathrm{T}$ cells. Clin Exp Immunol. 2015;180:255-70.

93. Perica K, Varela JC, Oelke M, Schneck J. Adoptive T cell immunotherapy for cancer. Rambam Maimonides Med J. 2015;6:e0004.

94. Rapoport APYJ. T-cell receptor (TCR)-gene modified T-cells for cancer: methods, data and challenges. In: Perales M-A, Abutalib SA, Bollard C, editors. Advances \& controversies in hematopoietic cell transplants and cell therapy. New York: Springer; 2018.

95. Morgan RA, Dudley ME, Wunderlich JR, Hughes MS, Yang JC, Sherry RM, et al. Cancer regression in patients after transfer of genetically engineered lymphocytes. Science. 2006;314:126-9.

96. Burns WR, Zheng Z, Rosenberg SA, Morgan RA. Lack of specific gamma-retroviral vector long terminal repeat promoter silencing in patients receiving genetically engineered lymphocytes and activation upon lymphocyte restimulation. Blood. 2009;114:2888-99.

97. Johnson LA, Morgan RA, Dudley ME, Cassard L, Yang JC, Hughes MS, et al. Gene therapy with human and mouse T-cell receptors mediates cancer regression and targets normal tissues expressing cognate antigen. Blood. 2009;114:535-46.

98. Robbins PF, Morgan RA, Feldman SA, Yang JC, Sherry RM, Dudley ME, et al. Tumor regression in patients with metastatic synovial cell sarcoma and melanoma using genetically engineered lymphocytes reactive with NY-ESO-1. J Clin Oncol: Off J Am Soc Clin Oncol. 2011;29:917-24.

99. Morgan RA, Chinnasamy N, Abate-Daga D, Gros A, Robbins $\mathrm{PF}$, Zheng Z, et al. Cancer regression and neurological toxicity following anti-MAGE-A3 TCR gene therapy. J Immunother. 2013;36:133-51. 
100. Linette GP, Stadtmauer EA, Maus MV, Rapoport AP, Levine BL, Emery L, et al. Cardiovascular toxicity and titin crossreactivity of affinity-enhanced $\mathrm{T}$ cells in myeloma and melanoma. Blood. 2013;122:863-71.

101. Park JH, Brentjens RJ. Adoptive immunotherapy for B-cell malignancies with autologous chimeric antigen receptor modified tumor targeted T cells. Discov Med. 2010;9:277-88.

102. Curran KJ, Pegram HJ, Brentjens RJ. Chimeric antigen receptors for $\mathrm{T}$ cell immunotherapy: current understanding and future directions. J Gene Med. 2012;14:405-15.

103. Maus MV, June CH. Making better chimeric antigen receptors for adoptive T-cell therapy. Clin Cancer Res. 2016;22:1875-84.

104. Kochenderfer JN, Wilson WH, Janik JE, Dudley ME, StetlerStevenson M, Feldman SA, et al. Eradication of B-lineage cells and regression of lymphoma in a patient treated with autologous $\mathrm{T}$ cells genetically engineered to recognize CD19. Blood. 2010;116:4099-102.

105. Porter DL, Levine BL, Kalos M, Bagg A, June CH. Chimeric antigen receptor-modified $\mathrm{T}$ cells in chronic lymphoid leukemia. N Eng J Med. 2011;365:725-33.

106. Brentjens RJ, Riviere I, Park JH, Davila ML, Wang X, Stefanski $\mathrm{J}$, et al. Safety and persistence of adoptively transferred autologous CD19-targeted $\mathrm{T}$ cells in patients with relapsed or chemotherapy refractory B-cell leukemias. Blood. 2011; 118:4817-28.

107. Savoldo B, Ramos CA, Liu E, Mims MP, Keating MJ, Carrum $\mathrm{G}$, et al. CD28 costimulation improves expansion and persistence of chimeric antigen receptor-modified $\mathrm{T}$ cells in lymphoma patients. J Clin Invest. 2011;121:1822-6.

108. Kalos M, Levine BL, Porter DL, Katz S, Grupp SA, Bagg A, et al. $T$ cells with chimeric antigen receptors have potent antitumor effects and can establish memory in patients with advanced leukemia. Sci Transl Med. 2011;3:95ra73.

109. Kochenderfer JN, Dudley ME, Feldman SA, Wilson WH, Spaner DE, Maric I, et al. B-cell depletion and remissions of malignancy along with cytokine-associated toxicity in a clinical trial of antiCD19 chimeric-antigen-receptor-transduced $\mathrm{T}$ cells. Blood. 2012;119:2709-20.

110. Cruz CR, Micklethwaite KP, Savoldo B, Ramos CA, Lam S, Ku $\mathrm{S}$, et al. Infusion of donor-derived CD19-redirected virus-specific $\mathrm{T}$ cells for B-cell malignancies relapsed after allogeneic stem cell transplant: a phase 1 study. Blood. 2013;122:2965-73.

111. Brentjens RJ, Davila ML, Riviere I, Park J, Wang X, Cowell LG, et al. CD19-targeted T cells rapidly induce molecular remissions in adults with chemotherapy-refractory acute lymphoblastic leukemia. Sci Transl Med. 2013;5:177ra38.

112. Grupp SA, Kalos M, Barrett D, Aplenc R, Porter DL, Rheingold $\mathrm{SR}$, et al. Chimeric antigen receptor-modified $\mathrm{T}$ cells for acute lymphoid leukemia. N Eng J Med. 2013;368:1509-18.

113. Davila ML, Riviere I, Wang X, Bartido S, Park J, Curran K, et al. Efficacy and toxicity management of 19-28z CAR T cell therapy in B cell acute lymphoblastic leukemia. Sci Transl Med. 2014;6:224ra25.

114. Maude SL, Frey N, Shaw PA, Aplenc R, Barrett DM, Bunin NJ, et al. Chimeric antigen receptor $\mathrm{T}$ cells for sustained remissions in leukemia. N Eng J Med. 2014;371:1507-17.

115. Park JH, Brentjens RJ. Are all chimeric antigen receptors created equal? J Clin Oncol. 2015;33:651-3.

116. Kochenderfer JN, Dudley ME, Kassim SH, Somerville RP, Carpenter RO, Stetler-Stevenson M, et al. Chemotherapyrefractory diffuse large B-cell lymphoma and indolent B-cell malignancies can be effectively treated with autologous $\mathrm{T}$ cells expressing an anti-CD19 chimeric antigen receptor. J Clin Oncol. 2015;33:540-9.

117. Lee DW, Kochenderfer JN, Stetler-Stevenson M, Cui YK, Delbrook C, Feldman SA, et al. T cells expressing CD19 chimeric antigen receptors for acute lymphoblastic leukaemia in children and young adults: a phase 1 dose-escalation trial. Lancet. 2015;385:517-28.

118. Porter DL, Hwang WT, Frey NV, Lacey SF, Shaw PA, Loren $\mathrm{AW}$, et al. Chimeric antigen receptor $\mathrm{T}$ cells persist and induce sustained remissions in relapsed refractory chronic lymphocytic leukemia. Sci Transl Med. 2015;7:303ra139.

119. Dai H, Zhang W, Li X, Han Q, Guo Y, Zhang Y, et al. Tolerance and efficacy of autologous or donor-derived $\mathrm{T}$ cells expressing CD19 chimeric antigen receptors in adult B-ALL with extramedullary leukemia. Oncoimmunology. 2015;4:e1027469.

120. Turtle CJ, Hanafi LA, Berger C, Gooley TA, Cherian S, Hudecek $\mathrm{M}$, et al. CD19 CAR-T cells of defined CD4+:CD8+ composition in adult B cell ALL patients. J Clin Invest. 2016; 126:2123-38.

121. Gardner R, Wu D, Cherian S, Fang M, Hanafi LA, Finney O, et al. Acquisition of a CD19-negative myeloid phenotype allows immune escape of MLL-rearranged B-ALL from CD19 CAR-Tcell therapy. Blood. 2016;127:2406-10.

122. Brudno JN, Kochenderfer JN. Toxicities of chimeric antigen receptor $\mathrm{T}$ cells: recognition and management. Blood. 2016;127:3321-30.

123. Maude S, Barrett DM. Current status of chimeric antigen receptor therapy for haematological malignancies. Br J Haematol. 2016;172:11-22.

124. Till BG, Jensen MC, Wang J, Chen EY, Wood BL, Greisman $\mathrm{HA}$, et al. Adoptive immunotherapy for indolent non-Hodgkin lymphoma and mantle cell lymphoma using genetically modified autologous CD20-specific T cells. Blood. 2008;112: 2261-71.

125. Cheadle EJ, Hawkins RE, Batha H, Rothwell DG, Ashton G, Gilham DE. Eradication of established B-cell lymphoma by CD19-specific murine $\mathrm{T}$ cells is dependent on host lymphopenic environment and can be mediated by CD $4+$ and $\mathrm{CD} 8+\mathrm{T}$ cells. $\mathrm{J}$ Immunother. 2009;32:207-18.

126. Wallen H, Thompson JA, Reilly JZ, Rodmyre RM, Cao J, Yee C. Fludarabine modulates immune response and extends in vivo survival of adoptively transferred CD8 $\mathrm{T}$ cells in patients with metastatic melanoma. PLoS ONE. 2009;4:e4749.

127. Topp MS, Gokbuget N, Stein AS, Zugmaier G, O'Brien S, Bargou RC, et al. Safety and activity of blinatumomab for adult patients with relapsed or refractory B-precursor acute lymphoblastic leukaemia: a multicentre, single-arm, phase 2 study. Lancet Oncol. 2015;16:57-66.

128. Lee DW, Gardner R, Porter DL, Louis CU, Ahmed N, Jensen M, et al. Current concepts in the diagnosis and management of cytokine release syndrome. Blood. 2014;124:188-95.

129. Neelapu SS, Tummala S, Kebriaei P, Wierda W, Gutierrez C, Locke FL, et al. Chimeric antigen receptor T-cell therapyassessment and management of toxicities. Nat Rev Clin Oncol. 2018;15:47-62.

130. Santomasso B,Park JH,Riviere I,Mead E,Halton E,Diamonte C, et al. Biomarkers associated with neurotoxicity in adult patients with relapsed or refractory B-ALL (R/R B-ALL) treated with CD19 CAR T cells. J Clin Oncol. 2017;35(15_suppl): 3019.

131. De Angelo DJG, Park A, Dinner JH, Mannis SN, Lunning GN, Khalde MA, et al. Clinical outcomes for the phase 2, single-arm, multicenter trial of JCAR015 in adult B-ALL (ROCKET Study). J Immunother Cancer. 2017;5(Suppl 2):P217.

132. Harris J OncLive [Internet] 2017. http://www.onclive.com/webexclusives/kite-reports-cerebral-edema-death-in-zuma1-car-tcelltrial. Accessed 17 Jan 2018.

133. van der Stegen SJ, Hamieh M, Sadelain M. The pharmacology of second-generation chimeric antigen receptors. Nat Rev Drug Discov. 2015;14:499-509. 
134. Gust J, Hay KA, Hanafi LA, Li D, Myerson D, Gonzalez-Cuyar LF, et al. Endothelial activation and blood-brain barrier disruption in neurotoxicity after adoptive immunotherapy with CD19 CAR-T cells. Cancer Discov. 2017;7: 1404-19.

135. Taraseviciute A, Kean L, Jensen MC. Creation of the first nonhuman primate model that faithfully recapitulates chimeric antigen receptor (CAR) $\mathrm{T}$ cell-mediated cytokine release syndrome (CRS) and neurologic toxicity following B celldirected CAR-T cell therapy. Blood. 2016;128:651.

136. Alter A, Duddy M, Hebert S, Biernacki K, Prat A, Antel JP, et al. Determinants of human B cell migration across brain endothelial cells. J Immunol. 2003;170:4497-505.

137. Mackall CLM, Miklos DB. Endothelial cell activation emerges as a driver of CAR-T cell associated neurotoxicity. Cancer Discov. 2017;7:1371-3. 